\title{
Speciation of Chromium in Water Samples after Dispersive Liquid-Liquid Microextraction, and Detection by Means of High-Resolution Continuum Source Atomic Absorption Spectrometry
}

\author{
Daniele S. Porto, ${ }^{a}$ Naomi Akiba, ${ }^{a}$ Marcone Augusto L. de Oliveira ${ }^{b}$ and \\ Ivanise Gaubeur*,a \\ ${ }^{a}$ Centro de Ciências Naturais e Humanas, Universidade Federal do ABC, Av. dos Estados, 5001, \\ 09210-971 Santo André-SP, Brazil \\ ${ }^{b}$ Departamento de Química, Universidade Federal de Juiz de Fora, Campus Universitário, \\ 36036-330 Juiz de Fora-MG, Brazil
}

\begin{abstract}
A newly analytical method has been developed to determine total chromium and speciation of this element in water samples through dispersive liquid-liquid microextraction combined with a high-resolution continuum source flame atomic absorption spectrometry. The most significant variables affecting complexation and extraction were optimized by using response surface methodology and univariate optimization. The best conditions for both the complexation and extraction elements in this study were: complexing agent ammonium pyrrolidine dithiocarbamate (APDC $\left.6.0 \mathrm{mmol} \mathrm{L}^{-1}\right) ; \mathrm{pH}$ at $2.0\left(\mathrm{Cr}^{\mathrm{VI}}\right)$ and at $7.0(\mathrm{Cr}$ total); $\mathrm{NaCl}(5 \% \mathrm{~m} / \mathrm{v}) ; 1$-undecanol $(50 \mu \mathrm{L})$ and ethanol $300\left(\mathrm{Cr}^{\mathrm{IV}}\right)$ and $275 \mu \mathrm{L}$ (total $\mathrm{Cr}$ ). Under optimal conditions, this method resulted in a $20-100 \mu \mathrm{g} \mathrm{L}^{-1}$ linear range for $\mathrm{Cr}^{\mathrm{VI}}$ and total chromium, detection limits of $0.35\left(\mathrm{Cr}^{\mathrm{VI}}\right)$ and $6.7 \mu \mathrm{g} \mathrm{L}^{-1}$ (total $\mathrm{Cr}$ ), as well as enriching factor of $26\left(\mathrm{Cr}^{\mathrm{VI}}\right)$ and 19 for total $\mathrm{Cr}$. The method accuracy was carried out by using certified water reference material (NIST CRM 1643e), and the results achieved were in agreement with the certified value ( $t$-test at a confidence interval of $95 \%$ ). The method developed was applied in samples of mineral water, tap water (the recovery values ranged from 88 to $115 \%$ ) and seawater.
\end{abstract}

Keywords: dispersive liquid-liquid microextraction, chromium, speciation, trace element, atomic absorption spectrometry

\section{Introduction}

Chromium is an element commonly found in rocks, animals, plants, soil, rivers and seawater, dusts and volcanic fumes, as well as in Earth's crust at a concentration of approximately $100 \mathrm{mg} \mathrm{kg}^{-1} .{ }^{1}$ Chromium in the environment can be of natural origins, such as rock and soil erosion, volcanic eruptions, or of anthropogenic origins, through the use of this chemical element in a range of industrial activities such as metallurgy (steel, aluminum and alloys), refractories (cement, glass and clay) and chemical industries (leather tanning, wood preservation and pigments). ${ }^{2}$ The second source is significantly responsible for $\mathrm{Cr}^{\mathrm{III}}$ and $\mathrm{Cr}^{\mathrm{VI}}$ in the environment.

Trivalent chromium, $\mathrm{Cr}^{\mathrm{III}}$, is essentially found in the mechanisms for metabolism of carbohydrates, lipids and

*e-mail: ivanise.gaubeur@ufabc.edu.br proteins, with a lower level of toxicity and less mobility than hexavalent chromium in the environment, due to the fact that the element is present in mineral structures, in the form of precipitates with some elements as iron, aluminum and/or manganese, and complexed with organic matter. ${ }^{3}$ In contrast, hexavalent chromium, $\mathrm{Cr}^{\mathrm{VI}}$, is said to be carcinogenic as it is highly permeable in biological membranes, this being related to the fact that the chromate ion is a predominant specie of $\mathrm{Cr}^{\mathrm{VI}}$ in physiological $\mathrm{pH}$, whose tetrahedral structure is similar to other ions, such as sulfate and phosphate, leading it to make a path into cells by carrying ions. ${ }^{4,5}$ Since chromium's toxicological properties are dependent on the element's oxidation state, it is, therefore, important to carry out the correspondent chemical speciation for quantification purposes of these species. ${ }^{5}$ On the other hand, considering the low concentrations of chromium found, for example, in natural water samples as $\mu \mathrm{g} \mathrm{L}{ }^{-1}$ it is important to follow a preconcentration procedure 
prior to the detection process. ${ }^{6}$ This procedure will allow the concentration and separation of the matrix analyte, aiming to further detectability and eliminate any expected effects of the matrix and foreign ions.?

The so-called dispersive liquid-liquid microextraction (DLLME) was created by Rezaee et al. ${ }^{8}$ in 2006 and consists of quickly inserting, with the aid of a microsyringe, a mixture of extractant and disperser solvents with an aqueous solution containing the analyte. The build-up of fine and disperse droplets in the extractant solvent allows for extraction the analyte. Among other advantages of DLLME, an important one is that can enhance the use of reduced volumes of organic solvents, at low cost, with quickness, good values of recovery and enrichment factors. ${ }^{9}$ DLLME has been widely used to determine organic and inorganic analytes, ${ }^{10}$ considering that for the second analyte a complexing agent is usually added, thus resulting in a hydrophobic complex for an extraction at a later stage. ${ }^{11}$ Dithiocarbamates (DTCs) are mostly used as complexing agents, forming stable and neutral complexes with a wide range of metals. ${ }^{12}$ Sodium diethyldithiocarbamate (DDTC) and ammonium pyrrolidine dithiocarbamate (APDC) are two of the most widely used in DLLME. ${ }^{13}$

Generally, the detection of metals after DLLME is carried out using absorption and atomic emission techniques. Some of the techniques most widely applied are flame atomic absorption spectrometry (FAAS) and graphite furnace absorption atomic spectrometry (GFAAS) ${ }^{13}$ Other detection methods have been combined with DLLME including inductively coupled plasma optical emission spectrometry (ICP OES), ${ }^{14}$ laser-induced breakdown spectrometry (LIBS) ${ }^{15-19}$ and tungsten coil atomic emission spectrometry (WCAES) ${ }^{20}$ In this work, the authors used a high-resolution continuum source flame atomic absorption spectrometry (HR-CS FAAS) for chromium detection, which in contrast with the line source (LS FAAS) uses a radiation source of high-intensity emission in continuum 190-850 nm (Xe short-arc lamp), a high-resolution double Echelle monochromator (DEMO) and a charge coupled device (CCD) array detector, allowing a resolution of ca. $2 \mathrm{pm}$ per pixel as well as an increased detection capacity. ${ }^{21-25}$

In this context, this work aims at developing an analytical method for determination and speciation of $\mathrm{Cr}$ in water samples (tap water, mineral water and seawater) by using the DLLME procedure combined with HR-CS FAAS. To do so, the authors of this study assessed two complexing agents widely used, DDTC and APDC. Those variables encountered in complexation and microextraction were optimized by using response surface methodology and univariate optimization, which makes it possible to look into the influences of such variances, as well as the interaction effects between them on the analytical response.

\section{Experimental}

Reagents and solutions

All the solutions used in this work were prepared with analytical-grade reagents and ultrapure water (Milli-Q Plus system, Millipore, Bedford, MA, EUA). The standard solutions of chromium were then prepared by diluting standard solutions of $\mathrm{K}_{2} \mathrm{CrO}_{4} 10 \%(\mathrm{~m} / \mathrm{v})$ and $\mathrm{Cr}^{\mathrm{III}}$ $1000 \mathrm{mg} \mathrm{L}^{-1}$ (Specsol, Jacareí, SP, Brazil).

DDTC and APDC (Sigma-Aldrich, St. Louis, MO, USA) were two complexing reagents used. For adjusting the values of $\mathrm{pH}$, solutions of sulfuric acid and ammonium hydroxide were used in different concentrations that resulted from diluting sulfuric acid at 95-97\% (Merck, Darmstadt, Germany) and ammonium hydroxide at $28-30 \%$ (Sigma-Aldrich).

In the DLLME procedure, this was used as an extractant solvent, i.e., 1-undecanol (Sigma-Aldrich) and disperser solvent ethanol $\geq 99.5 \%$ PA (Fluka Analytical). A NaCl solution $25 \%(\mathrm{~m} / \mathrm{v})$ obtained from Sigma-Aldrich reagent was used as an electrolyte.

To study the effect of foreign ions, solutions containing aluminum, barium, cadmium, calcium, lead, chlorite, cobalt, copper, iron, manganese, nickel, nitrate, potassium, sodium, sulfate and zinc were prepared by diluting the standard solutions with a concentration of $1000 \mu \mathrm{g} \mathrm{mL}-1$ (Ultra Scientific, USA).

To assess the method accuracy, a certified reference material (CRM) of water was used (NIST 1643e trace elements in water) from the National Institute of Standards and Technology (Gaithersburg, MD, USA). Tap water (from our lab in the city of Santo André, SP, Brazil), mineral water (bought locally) and seawater (from city of Santos, SP, Brazil) were used as real samples. The tap and mineral water samples were used without any previous treatment and to remove particle material from the seawater the sample was filtered using a $0.45 \mu \mathrm{m}$ pore size membrane filter.

\section{DLLME procedure}

For the complexation and extraction of chromium species by means of DLLME, different volumes of samples or reference solutions were transferred to a glass tube of $10 \mathrm{~mL}$. 


\section{For determining total chromium}

The $\mathrm{pH}$ value was adjusted with ammonium hydroxide $(\mathrm{pH} 7.0)$ then $600 \mu \mathrm{L}$ APDC $\left(90 \mathrm{mmol} \mathrm{L}^{-1}\right)$ and $1800 \mu \mathrm{L}$ $\mathrm{NaCl} 25 \%(\mathrm{~m} / \mathrm{v})$ solutions were added. The resulting solution was heated in a water bath at $80^{\circ} \mathrm{C}$ for 15 minutes ${ }^{26}$ and cooled at room temperature, then the mixture $50 \mu \mathrm{L}$ of 1-undecanol and $275 \mu \mathrm{L}$ of ethanol was added using a glass syringe. The separation of phases was carried out in a centrifuge at $2000 \mathrm{rpm}$ for 3 minutes. The organic phase was collected with a micropipette, then diluted in $200 \mu \mathrm{L}$ of ethanol and then all volume introduced into HR-CS FAAS, with the aid of a pipette tip.

\section{For the determination of $\mathrm{Cr}^{\mathrm{vl}}$}

After acidification with sulfuric acid $1 \mathrm{~mol} \mathrm{~L}^{-1}(\mathrm{pH} 2.0)$, $600 \mu \mathrm{L} \mathrm{APDC}\left(90 \mathrm{mmol} \mathrm{L}^{-1}\right)$ and $1800 \mu \mathrm{L} \mathrm{NaCl} 25 \%$ (m/v) were added. By using a glass syringe, the mixture $50 \mu \mathrm{L}$ of 1 -undecanol and $300 \mu \mathrm{L}$ of ethanol were added. The other steps followed the same procedure used for total chromium.

\section{For the determination of $\mathrm{Cr}^{\text {III }}$}

It was evaluated from the difference between the total $\mathrm{Cr}$ and $\mathrm{Cr}^{\mathrm{VI}}$ concentrations found using the above mentioned procedures.

Instrumentation

A pH meter model 780 Metrohm (Herisau, Switzerland) equipped with a combined glass electrode was used to measure $\mathrm{pH}$, a hotplate model IKA C-MAG HS 7 (Germany) was used to heat to $80{ }^{\circ} \mathrm{C}$, and a Quimis centrifuge model Q222T (São Paulo, Brazil) for speeding up the separation of phases. The stirred extracting and dispersing solvents were added to the sample through a glass syringe with a capacity of $1000 \mu \mathrm{L}$ (SGE Analytical Science, USA).

The detection of chromium by HR-CS FAAS was carried out through a ContrAA® 300 (Analytik Jena AG, Jena, Germany) equipped with a xenon short-arc lamp (XBO 301, $300 \mathrm{~W}$, GLE, Berlin, Germany) operating in hotspot mode. The measurements were made at $357.9 \mathrm{~nm}$, the main line of chromium. The other instrumentation conditions used were: air flow $490 \mathrm{~L} \mathrm{~h}^{-1}$, acetylene flow $110 \mathrm{~L} \mathrm{~h}^{-1}$, burner height $13 \mathrm{~mm}$, sample flow rate at $6 \mathrm{~mL} \mathrm{~min}^{-1}$ and spectral resolution $0.2 \mathrm{~nm}$.

\section{Results and Discussion}

Effect assessment of sample volume in analytical signal

In the proposed DLLME procedure, the volume produced within the organic phase, containing the analytes extracted in 1-undecanol, was $45 \mu \mathrm{L}$. Even after dilution, the final volume with ethanol did not enable the continuous nebulization process in the detection. As result, it was then decided to carry out discrete nebulization. Discrete volumes ( 50 to $200 \mu \mathrm{L}$ ) of a solution containing $\mathrm{Cr} 50 \mu \mathrm{g} \mathrm{\textrm {L } ^ { - 1 }}$ obtained from the DLLME procedure were manually added to a pipette tip ( 20 to $200 \mu \mathrm{L}$ ) connected to the nebulizer aspiration tube. ${ }^{27}$ By keeping the instrumental parameters as above mentioned and a reading time of $10 \mathrm{~s}$, transient signals were produced and then measured at peak area. Taking into account that the manual insertion of the sample can lead to a higher standard deviation of measurements, the sample volume selected was based on the peak area and corresponding relative standard deviations $(n=3)$. The intensity of peak area increased with the sample volume, and the relative standard deviations reached 15, 11, 7.0 and $7.7 \%$ for volumes of 50, 100, 150 and $200 \mu \mathrm{L}$, respectively. A sample volume insertion of $200 \mu \mathrm{L}$ was selected for further experiments.

Oviedo et $a l .{ }^{28}$ achieved analytical calibration curves by performing continuous and discrete nebulization of Mo in an aqueous and organic medium. The ratio of angular coefficients of analytical calibration curves of samples in an organic medium obtained by discrete and continuous nebulization was around 10, displaying an increased sensitiveness level. That is, another advantage from discrete nebulization in addition to a reduced sample volume.

\section{Optimization of flame composition in chromium detection}

A study was carried out for flame composition in chromium analytical signal. Five different flame compositions were assessed with acetylene flow rate at 40, 100, 105, 110 and $120 \mathrm{~L} \mathrm{~h}^{-1}$ and by also keeping the air flow rate at $490 \mathrm{~L} \mathrm{~h}^{-1}(\mathrm{C}: \mathrm{O} 0.40 ; 0.97 ; 1.0 ; 1.1$ and 1.2 , respectively). Figure 1 shows that the stoichiometric flame with a $\mathrm{C}: \mathrm{O} 0.40$ ratio has the lowest sensitiveness level. On the other hand, in an air-acetylene flame formed by composition of 490 and $110 \mathrm{~L} \mathrm{~h}^{-1}$ air-acetylene, respectively ( $\mathrm{C}: \mathrm{O} 1.1)$, it was observed the highest sensitiveness level. A strategy widely used to increase sensitiveness in determining chromium consists of using a reducing flame; ${ }^{29,30}$ however, as noticed in Figure 1, in higher flow rates of acetylene at $120 \mathrm{~L} \mathrm{~h}^{-1}$, for example, the reduction of sensitiveness can be the result of carbides formation which makes the atomization process difficult. Thus a flame composition of 490 and $110 \mathrm{~L} \mathrm{~h}^{-1}$ of air and acetylene, respectively, was selected for further experiments. 


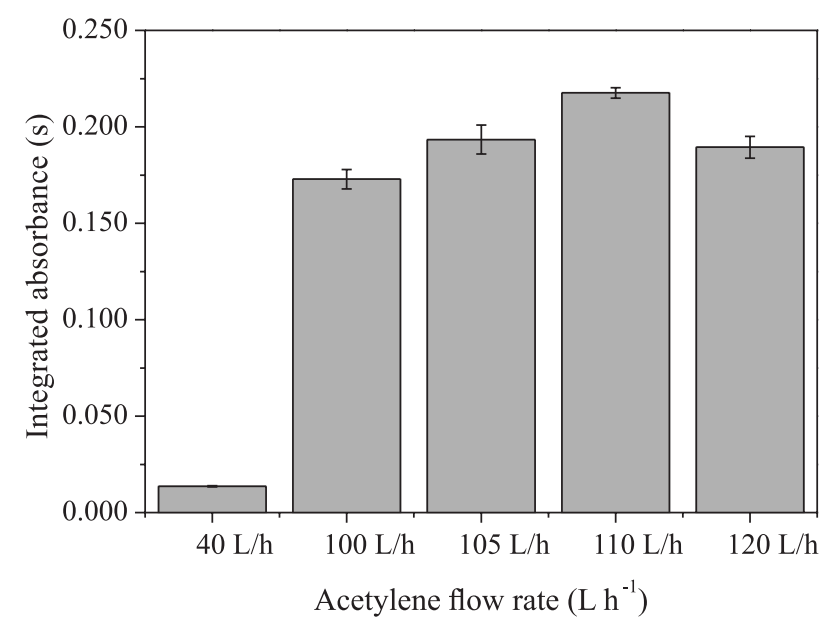

Figure 1. Flame composition study. Experimental conditions: $1000 \mu \mathrm{g} \mathrm{L}-1$ $\mathrm{Cr}^{\mathrm{III}}, 6.0 \mathrm{mmol} \mathrm{L}^{-1} \mathrm{APDC}, 0.02 \%$ (v/v) $\mathrm{NH}_{4} \mathrm{OH}(\mathrm{pH}=7.0), \mathrm{NaCl} 5 \%$ (m/v), $200 \mu \mathrm{L}$ of 1 -undecanol and $300 \mu \mathrm{L}$ ethanol. Air flow rate: $490 \mathrm{~L} \mathrm{~h}^{-1}$.

\section{DLLME procedure optimization}

The DLLME procedure was optimized by using multivariate designs in an Excel spreadsheet. The integrated absorbance signal achieved after microextraction was based on Origin ${ }^{\circledR}$, version 9.0 (Copyright ${ }^{\oplus}$ 1991-2012, OriginLab Corporation) and Statistica ${ }^{\circledR}$, version 10 (Copyright $^{\odot}$ 1984-2011, StatSoft). The optimization study was carried out independently for $\mathrm{Cr}^{\mathrm{III}}$ and $\mathrm{Cr}^{\mathrm{VI}}$.

In order to perform the first screening of assessed variables, a fractional factorial design $2{ }_{\mathrm{v}}^{5-1}$ was carried out. Table 1 shows all the factors studied and their respective levels, Table S1 (APDC complexant) and Table S2 (DDTC complexant) (Supplementary Information section) complete matrix of factorial design and integrated absorbance values.

Table 1. Factors and levels assessed to fractional factorial design $2{ }_{v}^{5-1}$

\begin{tabular}{lccc}
\hline \multirow{2}{*}{ Factor } & \multicolumn{3}{c}{ Level } \\
\cline { 2 - 4 } & $(-1)$ & $(0)$ & $(+1)$ \\
\hline $\mathrm{pH}$ & 2.0 & 4.5 & 7.0 \\
Complexant concentration / $\left(\mathrm{mmol} \mathrm{L}^{-1}\right)$ & 0.40 & 3.2 & 6.0 \\
Extractant volume / $\mu \mathrm{L}$ & 50 & 125 & 200 \\
Disperser volume / $\mu \mathrm{L}$ & 100 & 200 & 300 \\
$\mathrm{NaCl}(\mathrm{m} / \mathrm{v}) / \%$ & not added & 2.5 & 5.0 \\
\hline
\end{tabular}

Along with the results displayed in Tables S1 and S2, Pareto charts are presented in Figures $2 \mathrm{a}-2 \mathrm{~d}$, making it possible to assess the influence of variables and interaction between them on the analytical response. The horizontal bars represent the absolute values of estimated effects, while the vertical bar is known as a reference line. The effects that go beyond the reference line are significant for the analytical response within the confidence interval of $95 \%(p<0.05){ }^{31}$

Figures $2 \mathrm{a}$ and $2 \mathrm{~b}$ show that the two chromium species have the most significant effects for variables, $\mathrm{pH}$ value, complexant concentration and interaction between them, thus enhancing the importance of both variables in the DLLME procedure. At low $\mathrm{pH}$ values, $\mathrm{Cr}^{\mathrm{III}}$ is complexed with water molecules forming aqua complexes which are kinetically inert. By increasing $\mathrm{pH}$ value, the water molecules are then replaced with $\mathrm{OH}^{-}$ions, forming complexes with higher lability thus increasing the interaction of $\mathrm{Cr}^{\mathrm{III}}$ with complexant reagent molecules APDC and DDTC. ${ }^{26,32-37}$ The $\mathrm{pH}$ value is one of the variables allowing the speciation of chromium, as different from $\mathrm{Cr}^{\mathrm{III}}$, the hexavalent specie is immediately reduced to the trivalent form in the presence of the complexant agent, thus quickly forming the complexes.

Figure $2 \mathrm{c}$ indicates the same occurrence to variables, $\mathrm{pH}$ value, complexant concentration and interaction between them show significant. As for $\mathrm{Cr}^{\mathrm{VI}}$, Figure $2 \mathrm{~d}$, the only variable seen as significant was the disperser solvent (ethanol) volume.

Based on the results from the fractional factorial design and considering: ( $i$ ) the need to keep the concentration of complexants, APDC and DDTC, in excess related to the chromium species in order to ensure the quantitative complexation in the presence of other metal ions; (ii) the value of $\mathrm{pH}$ is one of the variables allowing the speciation of chromium; (iii) the increase of extractant solvent volume (1-undecanol) results in a reduced analytical signal due to lower enrichment factor; and ( $i v)$ the increase of electrolyte concentration displayed a positive effect on complex $\mathrm{Cr}$ III/APDC it was then decided to carry out a factorial design $3^{2}$ with variables, $\mathrm{pH}$ value and disperser solvent in complexation and extraction of $\mathrm{Cr}^{\mathrm{III}}$ with APDC and DDTC. The remaining variables such as $6.0 \mathrm{mmol} \mathrm{L}^{-1}$ of APDC and DDTC (highest level), $50 \mu \mathrm{L}$ of 1-undecanol (lowest level), $5.0 \%(\mathrm{~m} / \mathrm{v})$ of $\mathrm{NaCl}$ (highest level) for $\mathrm{Cr}$ III/APDC and $0.0 \%$ (no addition) of $\mathrm{NaCl}$ (lowest level) for $\mathrm{Cr}$ III/DDTC were kept constant.

The design experimental matrix generated a total of 11 experiments, and the values of integrated absorbance are shown in Table S3 (Supplementary Information section). Table 2 shows statistical results calculated to $3^{2}$ factorial design.

Taking into account the results presented in Table 2, it can be observed that just the average was considered significant within $95 \%$ confidence interval ( $p$-value $<0.05)$. The factors investigated did not present significance within $95 \%$ interval because all $p$-values were higher than 0.05 . 

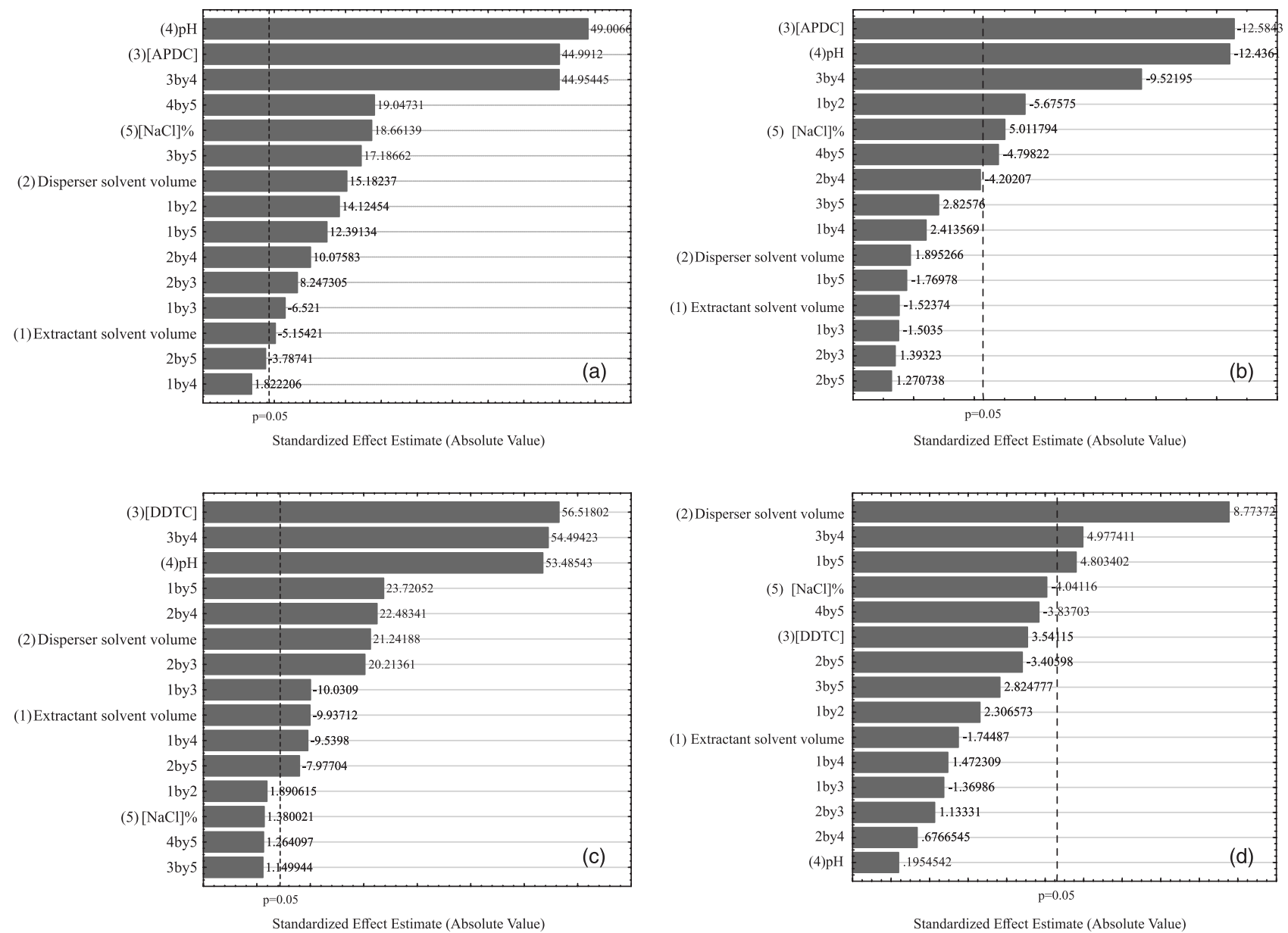

Figure 2. Pareto charts achieved in optimizing factors from fractional factorial design $2 \mathrm{v}^{5-1}$ (a) $\mathrm{Cr}^{\mathrm{III}}$ with APDC; (b) $\mathrm{Cr}^{\mathrm{VI}}$ with APDC; (c) Cr ${ }^{\mathrm{III}}$ with DDTC; (d) $\mathrm{Cr}^{\mathrm{VI}}$ with DDTC.

Table 2. Statistical results for $3^{2}$ factorial design

\begin{tabular}{|c|c|c|c|c|c|c|}
\hline \multirow{2}{*}{ Factor } & \multicolumn{3}{|c|}{$\mathrm{Cr}^{\mathrm{III}}$ with APDC } & \multicolumn{3}{|c|}{$\mathrm{Cr}^{\mathrm{III}}$ with DDTC } \\
\hline & Coefficient & Error & $p$-value & Coefficient & Error & $p$-value \\
\hline Constant & 0.067 & 0.011 & 0.024 & 0.827 & 0.146 & 0.030 \\
\hline $\mathrm{X}_{1}$ & 0.014 & 0.008 & 0.231 & 0.249 & 0.117 & 0.166 \\
\hline $\mathrm{X}_{2}$ & 0.002 & 0.008 & 0.866 & 0.030 & 0.117 & 0.821 \\
\hline $\mathrm{X}_{1} \mathrm{X}_{1}$ & 0.005 & 0.013 & 0.755 & -0.325 & 0.179 & 0.212 \\
\hline $\mathrm{X}_{2} \mathrm{X}_{2}$ & -0.042 & 0.013 & 0.084 & -0.194 & 0.179 & 0.390 \\
\hline $\mathrm{X}_{1} \mathrm{X}_{2}$ & $-2 \mathrm{E}-04$ & 0.010 & 0.989 & 0.010 & 0.143 & 0.951 \\
\hline
\end{tabular}

APDC: ammonium pyrrolidine dithiocarbamate; DDTC: sodium diethyldithiocarbamate.

The lack of fit test returned $\mathrm{F}_{\text {calculated }}\left(\mathrm{MS}_{\text {lack of fit }} / \mathrm{MS}_{\text {pure error }}\right)$ equal to 4.33 for $\mathrm{Cr}^{\mathrm{III}} / \mathrm{APDC}$ and 0.57 for $\mathrm{Cr}$ III/DDTC, lower than $\mathrm{F}_{\text {critical } 0.05, \mathrm{vl}=3, \mathrm{v} 2=2}=19.16$, which indicates absence of lack of fit within $95 \%$ confidence interval (Tables S4 and S5, Supplementary Information section). The regression significance test returned the value of $\mathrm{F}_{\text {calculated }}$ $\left(\mathrm{MS}_{\text {model }} / \mathrm{MS}_{\text {residual }}\right)$ equal to 0.91 for $\mathrm{Cr}$ III/APDC and 2.84 for $\mathrm{Cr}$ III/DDTC, lower than $\mathrm{F}_{\text {critical } 0.05, \mathrm{n} \mathrm{n}=5, \mathrm{n} 2=5}=5.05$ which indicates a no significant regression within $95 \%$ confidence interval (Tables S4 and S5, Supplementary Information section). ${ }^{31}$ However, taking into account that the percentage of variation explained by regression and maximum percentage of variation explained can be considered acceptable and the models residue for $\mathrm{Cr}^{\mathrm{III}} / \mathrm{APDC}$ and $\mathrm{Cr}^{\mathrm{III}} / \mathrm{DDTC}$ presented normal behavior through Shapiro-Wilk test for $95 \%$ confidence ( $p$-value $>0.05$ ), the response surface was built from the experiments.

Figures $3 \mathrm{a}$ and $3 \mathrm{~b}$, these graphs show that by using APDC, optimal conditions for DLLME were disperser solvent volume $275 \mu \mathrm{L}$ and $\mathrm{pH}$ value 7.0, and also using 
DDTC the best conditions for DLLME corresponded to the central point, that is, $275 \mu \mathrm{L}$ of disperser solvent and $\mathrm{pH}$ value of 6.5 .

For $\mathrm{Cr}^{\mathrm{VI}}$ based on the results obtained from the fractional factorial design, Figures $2 \mathrm{~b}$ and $2 \mathrm{~d}$, and considering: (i-iii) as previously mentioned for $\mathrm{Cr}^{\mathrm{III}}$; (iv) that the increase of concentration of electrolyte displayed a positive effect on complex $\mathrm{Cr}^{\mathrm{VI} / \mathrm{APDC}}$ and $(v)$ that the only significant variable for $\mathrm{Cr}^{\mathrm{v} /} / \mathrm{DDTC}$ was the disperser solvent volume, it was also decided to assess the disperser solvent (ethanol) volume influence on microextraction of $\mathrm{Cr}^{\mathrm{VI}}$ with DDTC. The other variables were maintained fixed: $6.0 \mathrm{mmol} \mathrm{L}^{-1}$ of DDTC (highest level), pH value 2.0 (lowest level), $0.0 \%$ (no addition) of $\mathrm{NaCl}$ (lowest level) and $50 \mu \mathrm{L}$ of 1-undecanol (lowest level).

Figure 4 shows an increased integrated absorbance up to $280 \mu \mathrm{L}$ of disperser solvent. In DLLME, the disperser solvent promotes the extractant solvent dispersion in aqueous solution, but an excess of disperser solvent should be avoided due to an increase in solubility of hydrophobic complex in aqueous phase, thus its reduced quantity in the organic phase. ${ }^{19}$ Even though the integrated absorbance displayed a slight increase at 310 and $320 \mu \mathrm{L}$ of disperser solvent (Figure 4) the analytical signal was kept below the initial volumes, 250 and $260 \mu \mathrm{L}$. As the extraction efficiency was higher between 270 and $280 \mu \mathrm{L}$ of disperser solvent, we decided then to keep the volume of $275 \mu \mathrm{L}$ for remaining part of this study.

In summary, using DDTC the selected experimental conditions as follows: value of $\mathrm{pH} 2.0$ for $\mathrm{Cr}^{\mathrm{VI}}$ and $\mathrm{pH} 6.5$ for total $\mathrm{Cr}$, concentration of DDTC $6.0 \mathrm{mmol} \mathrm{L}^{-1}$, with no addition of $\mathrm{NaCl}, 50 \mu \mathrm{L}$ for 1-undecanol and $275 \mu \mathrm{L}$ of ethanol. By using APDC, conditions as follows: value of $\mathrm{pH} 2.0$ for $\mathrm{Cr}^{\mathrm{VI}}$ and $\mathrm{pH} 7.0$ for total $\mathrm{Cr}$, concentration

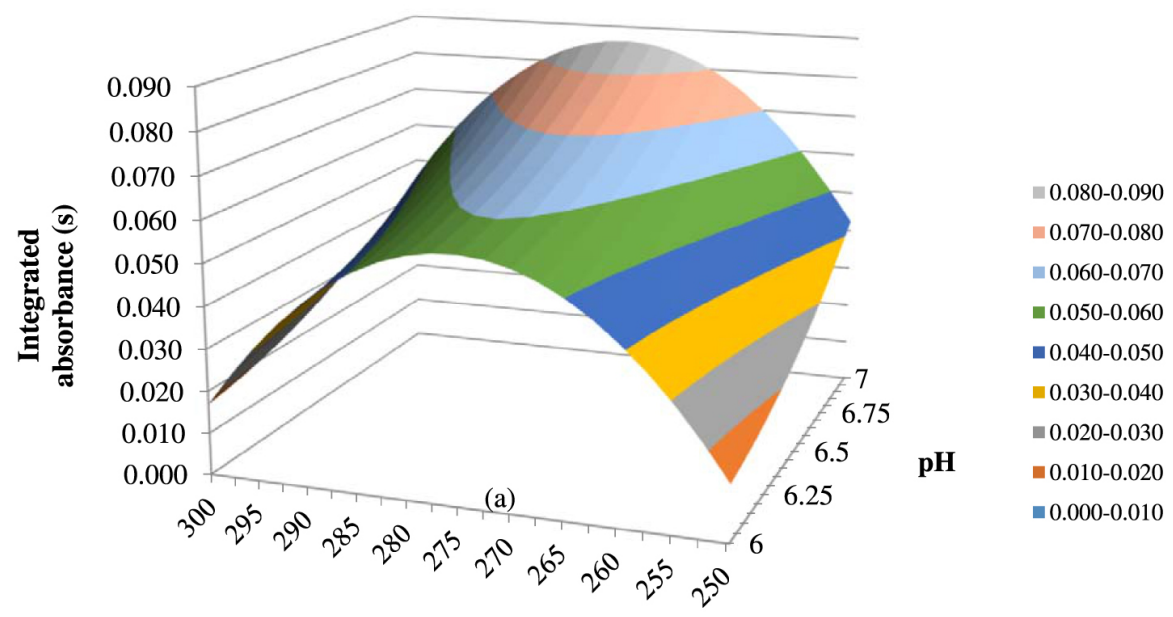

Volume of solvent disperser $(\mu \mathrm{L})$

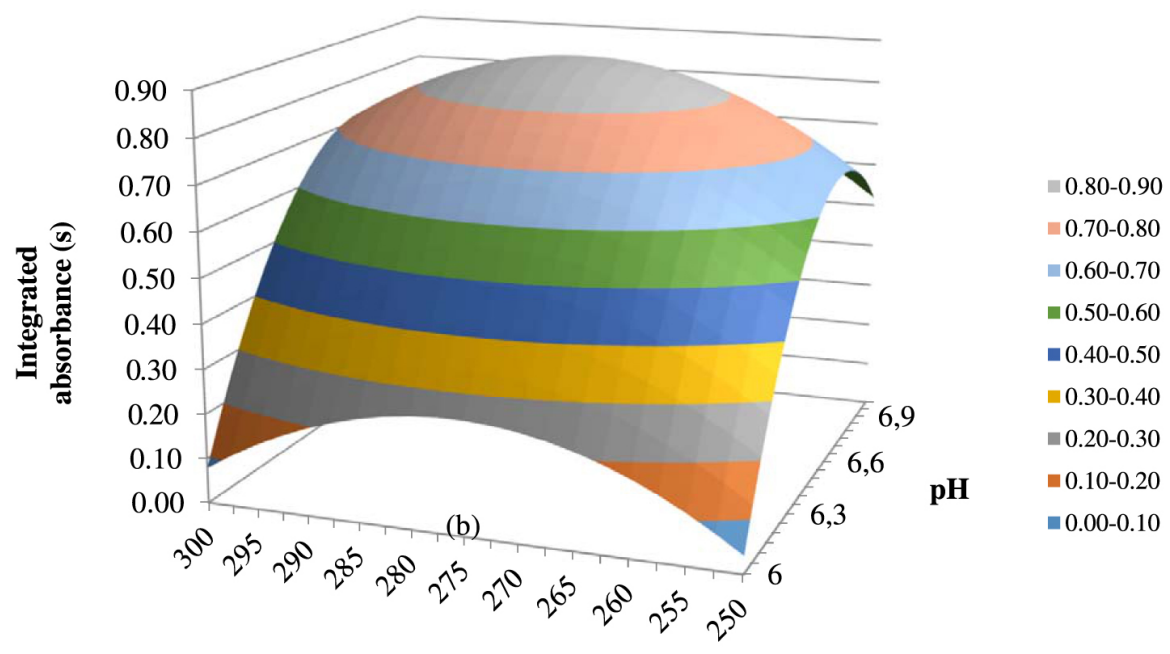

Volume of solvent disperser $(\mu \mathrm{L})$

Figure 3. Response surface graphs for response of factorial design $3^{2}$. (a) $\mathrm{Cr}^{\text {III }}$ with APDC; (b) $\mathrm{Cr}^{\text {III }}$ with DDTC. 


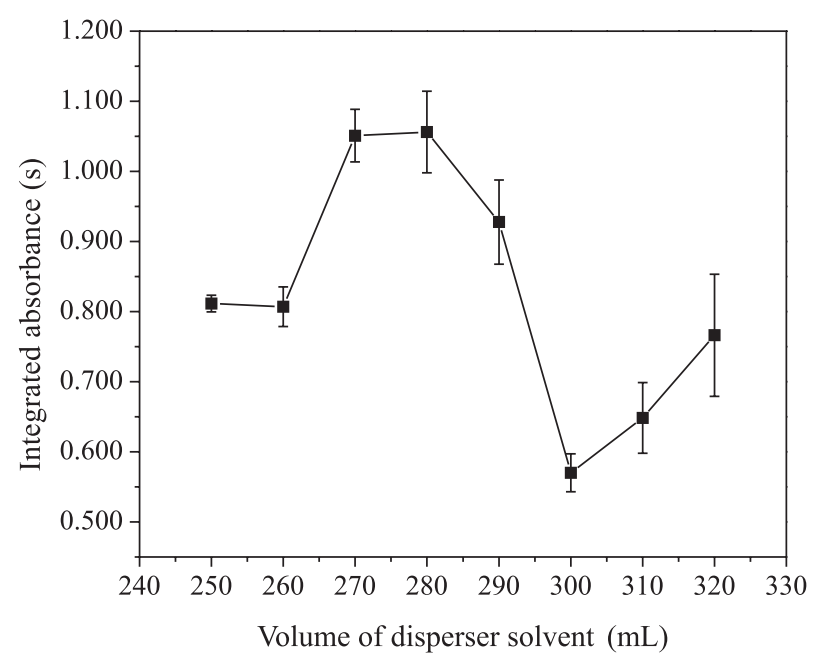

Figure 4. Effect of disperser solvent (ethanol) volume for $\mathrm{Cr}^{\mathrm{VI}}$ using DDTC. Experimental conditions: $1000 \mu \mathrm{g} \mathrm{L}^{-1} \mathrm{Cr}^{\mathrm{VI}}, \mathrm{H}_{2} \mathrm{SO}_{4}(\mathrm{pH}=2.0)$, $6.0 \mathrm{mmol} \mathrm{L}^{-1}$ DDTC and $50 \mu \mathrm{L}$ of 1-undecanol.

of APDC $6.0 \mathrm{mmol} \mathrm{L}^{-1}, 5.0 \%(\mathrm{~m} / \mathrm{v}) \mathrm{NaCl}, 50$ and $275 \mu \mathrm{L}$ of 1-undecanol and ethanol, respectively, for total $\mathrm{Cr}$ and $300 \mu \mathrm{L}$ of ethanol for $\mathrm{Cr}^{\mathrm{VI}}$.

The reaction between $\mathrm{Cr}^{\mathrm{III}}$ and $\mathrm{APDC}$ is then accelerated by heating the solution prior to the extraction procedure. ${ }^{26,33,35,36}$ To assess the influence of temperature and time on formation of the $\mathrm{Cr}^{\mathrm{III}}$ complex with APDC after adjusting $\mathrm{pH}$ value (7.0) and addition of APDC $\left(6.0 \mathrm{mmol} \mathrm{L}^{-1}\right)$ to an aqueous solution containing $50 \mu \mathrm{g} \mathrm{L}{ }^{-1}$ of $\mathrm{Cr}^{\mathrm{IIII}}$, the resulting solution was heated to $80{ }^{\circ} \mathrm{C}$ for 15 minutes ${ }^{26}$ and after cooling at room temperature, microextraction took place. Integrated absorbance increased by 32 times in compared with the absorbance achieved without the heat step, thus showing the importance of the latter in higher sensitivity.

To select the type of complexant, the DLLME procedure was followed $(\mathrm{n}=3)$, using experimental conditions previously selected and a heating step using APDC at $\mathrm{pH}$ 7.0, in aqueous solutions containing a mixture of $\mathrm{Cr}^{\mathrm{III}}$ and $\mathrm{Cr}^{\mathrm{VI}}$ $50 \mu \mathrm{g} \mathrm{L}^{-1}$. The selection of complexant was based on both the peak area and the relative standard deviations (RSD). At $\mathrm{pH} 2.0\left(\mathrm{Cr}^{\mathrm{VI}}\right)$, integrated absorbance corresponded to 0.129 (RSD 21\%) and 0.257 (RSD 3.2\%) for DDTC and APDC, respectively. For total chromium-pH 6.5 (DDTC) and $\mathrm{pH} 7.0$ (APDC)-the values of integrated absorbance were respectively 0.469 (RSD 9.3\%) and 0.418 (RSD $0.98 \%$ ). Apart from the lowest relative standard deviation using $\mathrm{APDC}$ for $\mathrm{Cr}^{\mathrm{VI}}$ and total chromium, it was possible to notice that the analytical signal was twice as high for determining $\mathrm{Cr}^{\mathrm{VI}}$ with APDC. It was then decided to use APDC as the complexant in the DLLME procedure proposed for determination and speciation of chromium. Table 3 shows optimal conditions for the DLLME procedure as well as for detection by HR-CS FAAS.

\section{Analytical features of the proposed method}

The analytical curves were achieved with and without the DLLME procedure (DLLME-HR-CS FAAS and HR-CS FAAS). Both curves were also obtained in triplicate and for the analytical curve without the DLLME procedure, the standards solutions of $\mathrm{Cr}$ were prepared in a medium of ethanol. Table 4 summarizes the analytical features for DLLME-HR-CS FAAS and HR-CS FAAS.

Table 3. Commitment conditions used for chromium speciation and detection

\begin{tabular}{|c|c|}
\hline Variable & Condition \\
\hline Complexant agent & APDC \\
\hline Concentration / $\left(\mathrm{mmol} \mathrm{L}^{-1}\right)$ & 6.0 \\
\hline $\mathrm{pH}$ & $\begin{array}{c}2.0\left(\mathrm{Cr}^{\mathrm{VI}}\right) \\
7.0(\text { total } \mathrm{Cr})\end{array}$ \\
\hline $\mathrm{NaCl}(\mathrm{m} / \mathrm{v}) / \%$ & 5.0 \\
\hline Heat temperature and time & total $\mathrm{Cr} 80^{\circ} \mathrm{C}$ for $15 \mathrm{~min}$ \\
\hline Extractant solvent / $\mu \mathrm{L}$ & 50 (1-undecanol) \\
\hline Disperser solvent / $\mu \mathrm{L}$ & $\begin{array}{c}300\left(\mathrm{Cr}^{\mathrm{VI}}\right) \\
275(\text { total } \mathrm{Cr})\end{array}$ \\
\hline Centrifugation condition / rpm & 2000 (for $3 \mathrm{~min}$ ) \\
\hline Organic phase diluent / $\mu \mathrm{L}$ & 200 (ethanol) \\
\hline \multicolumn{2}{|l|}{ Instrumental parameter } \\
\hline Wavelength / nm & 357.9 \\
\hline Flame composition / $\left(\mathrm{L} \mathrm{h}^{-1}\right)$ & 490 (air); 110 (acetylene) \\
\hline Burner height / mm & 13 \\
\hline Nebulization type & discrete \\
\hline Aspiration rate / $\left(\mathrm{mL} \min ^{-1}\right)$ & 6 \\
\hline Analytical signal & peak area \\
\hline Time of integration / s & 10 \\
\hline
\end{tabular}

By comparing the angular coefficient of the analytical curves with and without the DLLME procedure, an increased level of sensitivity was obtained (26 times for $\mathrm{Cr}^{\mathrm{VI}}$ and 19 times for total $\mathrm{Cr}$ ). The combination of DLLME and HR-CS FAAS made it possible to reach quantification limits considerably below the acceptable levels of $\mathrm{Cr}$ established for drinking water by the World Health Organization (WHO) ${ }^{38}$ Brazil's Ministry of Health ${ }^{39}$ and European Drinking Water Directive of the European Union Council (EUC) ${ }^{40}$ of $50 \mu \mathrm{g} \mathrm{L}^{-1}$ and the Environmental Protection Agency (EPA) of $100 \mu \mathrm{g} \mathrm{L} \mathrm{L}^{-1} .^{41}$

\section{Effect of foreign ions}

The study of interfering elements is carried out, in general, in an univariate way, where only one ion is assessed at a time, although this type of study requires a 
Table 4. Analytical features of DLLME-HR-CS FAAS and HR-CS FAAS methods for $\mathrm{Cr}^{\mathrm{VI}}$ and $\mathrm{Cr}$ total

\begin{tabular}{|c|c|c|}
\hline DLLME-HR-CS FAAS & $\mathrm{Cr}^{\mathrm{VI}}$ & Cr total \\
\hline Analytical curve equation & $\mathrm{A}=5.1( \pm 0.2) \times 10^{-3} \mathrm{C}_{\mathrm{CrVI}}+1.3( \pm 5.0) \times 10^{-3}$ & $\mathrm{~A}=3.7( \pm 0.2) \times 10^{-3} \mathrm{C}_{\text {Cr total }}+15( \pm 6) \times 10^{-3}$ \\
\hline $\mathrm{R}^{2 \mathrm{a}}$ & 0.9987 & 0.9998 \\
\hline Linear range / $\left(\mu \mathrm{g} \mathrm{L}^{-1}\right)$ & $20-100$ & $20-100$ \\
\hline $\mathrm{LOD} /\left(\mu \mathrm{g} \mathrm{L}^{-1}\right)$ & 0.35 & 6.7 \\
\hline $\mathrm{LOQ} /\left(\mu \mathrm{g} \mathrm{L}^{-1}\right)$ & 1.1 & 22 \\
\hline Repeatability (RSD) ${ }^{\mathrm{b}} / \%$ & 7 & 18 \\
\hline Relative sensitivity $^{\mathrm{c}}$ & 26 & 19 \\
\hline HR-CS FAAS & \multicolumn{2}{|c|}{ Chromium } \\
\hline Analytical curve equation & \multicolumn{2}{|c|}{$\mathrm{A}=0.198( \pm 0.006) \mathrm{C}_{\mathrm{Cr} \text { total }}+0.028( \pm 0.006)$} \\
\hline $\mathrm{R}^{2 \mathrm{a}}$ & \multicolumn{2}{|c|}{0.9994} \\
\hline Linear range / $\left(\mathrm{mg} \mathrm{L}^{-1}\right)$ & \multicolumn{2}{|c|}{$0.5-3.0$} \\
\hline $\mathrm{LOD} /\left(\mathrm{mg} \mathrm{L}^{-1}\right)$ & \multicolumn{2}{|c|}{0.032} \\
\hline $\mathrm{LOQ} /\left(\mathrm{mg} \mathrm{L}^{-1}\right)$ & \multicolumn{2}{|c|}{0.11} \\
\hline
\end{tabular}

${ }^{a}$ Number of calibration points, $\mathrm{n}=8$; belative standard deviation, $\mathrm{n}=10, \mathrm{Cr}^{\mathrm{Vl}} 20 \mu \mathrm{g} \mathrm{L}{ }^{-1}$ and Cr total $80 \mu \mathrm{g} \mathrm{L}{ }^{-1}$; ${ }^{\mathrm{c}}$ sensitivity DLLME-HR-CS FAAS/sensitivity HR-CS FAAS; DLLME-HR-CS FAAS: dispersive liquid-liquid microextraction high-resolution continuum source flame atomic absorption spectrometry; LOD: limit of detection; LOQ: limit of quantification.

long time frame, as the ions are simultaneously present in the sample. In this paper, the study of foreign ions was conducted in a multivariate way by means of a two-level Plackett-Burman design allowing the calculation of the main effects of an experimental set through a reduced number of experiments. ${ }^{42,43}$

The foreign ions assessed were the following: aluminum, barium, cadmium, calcium, lead, chloride, cobalt, copper, iron, manganese, nickel, nitrate, potassium, sodium, sulfate and zinc. Except for chloride anions, nitrate and sulfate, the selection for the concentration of foreign ions was based on the value stated in the certified reference material NIST CRM 1643e (trace elements in water). The concentrations of foreign ions and levels assessed in the Plackett-Burman design are shown in Table S6 (Supplementary Information section).

Based on the design used, a matrix was designed with 27 experiments, out of which three correspond to the triplicate in the central point. For the DLLME procedure, the solution used was one containing $50 \mu \mathrm{g} \mathrm{L}-1$ $\mathrm{Cr}^{\mathrm{VI}}$ and $\mathrm{Cr}^{\mathrm{III}}$ in the presence of foreign ions as well as in the conditions previously set (Table 3 ). The entire matrix and integrated absorbance values are displayed in Tables S7 and S8 (Supplementary Information section). Such values were used to design Pareto charts, Figures $5 \mathrm{a}$ and $5 \mathrm{~b}$, where it can be noticed that in the conditions as selected for the DLLME procedure, all the foreign ions did not interfere in the complexation, microextraction and detection of chromium, due to the fact that the variances encountered did not deviate any further from the reference line. As a result, they were not seen as significant for the analytical response within the confidence interval of $95 \%(p<0.05)$.
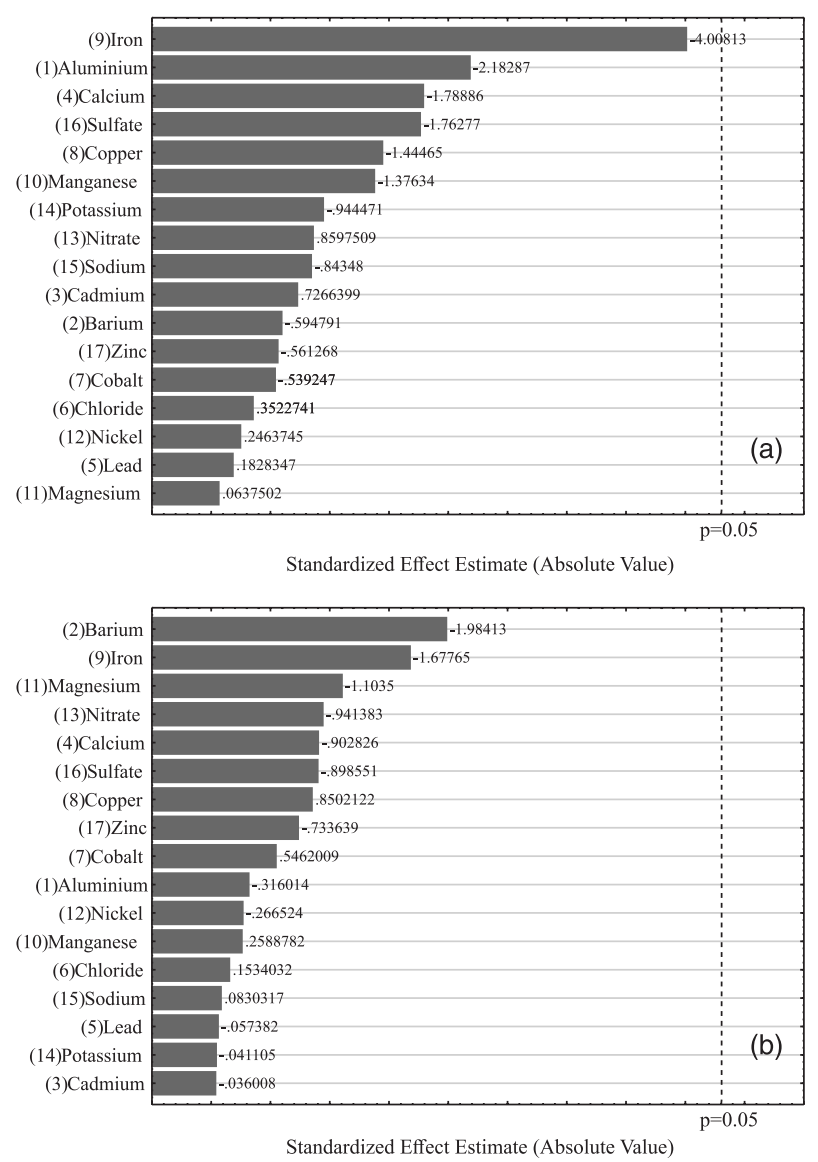

Figure 5. Pareto chart achieved from Plackett-Burman factorial design aiming at the effect of interfering ions in optimized conditions of extraction and detection at (a) $\mathrm{pH} 2.0$; (b) $\mathrm{pH} 7.0$.

Assessment of accuracy evaluation and applicability of the method to water samples

Table 5 shows the results obtained for the addition and 
recovery trials of $\mathrm{Cr}^{\mathrm{III}}$ and $\mathrm{Cr}^{\mathrm{VI}}$ in different water samples and for determining $\mathrm{Cr}^{\mathrm{III}}$ on certified reference material NIST CRM 1643e (trace elements in water). Recovery values ranged from 88 to $115 \%$, suggesting that the proposed method is free from matrix effect. According to the $t$-test carried out (at a confidence interval of 95\%) there, were no significant differences between the values set and certified in the water reference material.

The proposed method was also applied to the detection of $\mathrm{Cr}$ in seawater, but both species of $\mathrm{Cr}$ were not detected. In order to compare the obtained results, total $\mathrm{Cr}$ was determined for mineral water 3 and seawater samples using the graphite furnace absorption atomic spectrometry (GFAAS) method. Table S9 (Supplementary Information section) presents information about the heating program using GFAAS, and some analytical features provided by the method. As obtained for the proposed method, $\mathrm{Cr}$ was not detected in both samples using GFAAS (LOD: 0.03 and LOQ: $0.10 \mu \mathrm{g} \mathrm{L}^{-1}$ ).

\section{Comparison of the proposed method with those previous reported}

Table 6 shows a comparison of some experimental conditions and analytical features with those attained in procedures for $\mathrm{Cr}$ speciation and/or determination using liquid phase microextraction (LPME) procedures and FAAS detection. ${ }^{26,27,44-46}$ The proposed method leads to detection limits higher than or comparable to the ones obtained by using different chelating reagents and extractant solvents. The proposed DLLME procedure uses a reduced volume of non-chloride solvents and low toxicity by combining 1-undecanol as an extractant solvent and ethanol as a disperser solvent. Moreover, the speciation of $\mathrm{Cr}$ was performed without adding any other reagent such as $\mathrm{KMnO}_{4}$ for the oxidation of $\mathrm{Cr}^{\mathrm{III}}$ to $\mathrm{Cr}^{\mathrm{VI}}$ or $\mathrm{Na}_{2} \mathrm{SO}_{3}$ to reduce $\mathrm{Cr}^{\mathrm{VI}}$ to $\mathrm{Cr}^{\mathrm{III}}$, and the organic phase was introduced without any previous evaporation of chloride solvent.

The results presented in the study of influence from other ions, Figures $5 \mathrm{a}$ and $5 \mathrm{~b}$, as well as those presented in Table 5 showed the good method selectivity without the need to add masking agent such as ethylenediamine tetraacetic acid (EDTA), that are at times necessary to the elimination of the interference of other ions, $\mathrm{Co}, \mathrm{Fe}$ and $\mathrm{Ni}$, for the detection of $\mathrm{Cr}$ by FAAS. ${ }^{26,35,36} \mathrm{The}$ combination of DLLME with HR-CS-FAAS to detect $\mathrm{Cr}$ presents, in addition to the advantages previously showed, the possibility to a simultaneous correction of the background within the proximities of the analytical line, enabling to view the spectral region around the analytical line and automatic correction covering every continuum events. ${ }^{24}$

\section{Conclusions}

The development of analytical methods that allow speciation and determination of potentially toxic chemical

Table 5. Determination of $\mathrm{Cr}^{\mathrm{III}}$ and $\mathrm{Cr}^{\mathrm{VI}}$ in water samples and certified reference materials using the proposed DLLME-HR-CS FAAS method

\begin{tabular}{|c|c|c|c|c|c|c|c|c|}
\hline \multirow{2}{*}{ Sample } & \multicolumn{2}{|c|}{ Added / $\left(\mu \mathrm{g} \mathrm{L}^{-1}\right)$} & \multicolumn{3}{|c|}{ Found concentration $^{\mathrm{a}} /\left(\mu \mathrm{g} \mathrm{L}^{-1}\right)$} & \multicolumn{3}{|c|}{ Recovery / \% } \\
\hline & $\mathrm{Cr}^{\mathrm{III}}$ & $\mathrm{Cr}^{\mathrm{VI}}$ & $\mathrm{Cr}^{\Pi I I b}$ & $\mathrm{Cr}^{\mathrm{VI}}$ & Cr total & $\mathrm{Cr}^{\mathrm{III}}$ & $\mathrm{Cr}^{\mathrm{VI}}$ & Cr total \\
\hline \multirow{4}{*}{ Tap water } & 0.0 & 0.0 & - & $<\mathrm{LOQ}$ & $<\mathrm{LOQ}$ & - & - & - \\
\hline & 20 & 20 & $19 \pm 2$ & $19.7 \pm 0.1$ & $39 \pm 2$ & 96 & 98 & 97 \\
\hline & 30 & 30 & $32 \pm 8$ & $31 \pm 4$ & $63 \pm 5$ & 107 & 103 & 105 \\
\hline & 40 & 40 & $36 \pm 15$ & $39 \pm 5$ & $75 \pm 12$ & 90 & 98 & 94 \\
\hline \multirow{4}{*}{ Mineral water 1} & 0.0 & 0.0 & - & $<\mathrm{LOQ}$ & $<\mathrm{LOQ}$ & - & - & - \\
\hline & 20 & 20 & $18 \pm 5$ & $22 \pm 1$ & $40 \pm 4$ & 90 & 108 & 100 \\
\hline & 30 & 30 & $31 \pm 3$ & $33 \pm 1$ & $64 \pm 3$ & 103 & 111 & 107 \\
\hline & 40 & 40 & $36 \pm 13$ & $40 \pm 1$ & $76 \pm 11$ & 90 & 100 & 95 \\
\hline \multirow{4}{*}{ Mineral water 2} & 0.0 & 0.0 & - & $<\mathrm{LOQ}$ & $<\mathrm{LOQ}$ & - & - & - \\
\hline & 20 & 20 & $20 \pm 10$ & $23 \pm 2$ & $43 \pm 11$ & 100 & 114 & 107 \\
\hline & 30 & 30 & $26 \pm 19$ & $32 \pm 3$ & $58 \pm 17$ & 88 & 106 & 97 \\
\hline & 40 & 40 & $38 \pm 17$ & $43 \pm 2$ & $81 \pm 18$ & 95 & 108 & 101 \\
\hline \multirow{3}{*}{ Mineral water 3} & 0.0 & 0.0 & - & $<\mathrm{LOQ}$ & $<\mathrm{LOQ}$ & - & - & - \\
\hline & 20 & 2 & $23 \pm 2$ & $1.9 \pm 0.5$ & $25 \pm 2$ & 115 & 93 & 114 \\
\hline & 50 & 20 & $56 \pm 1$ & $20 \pm 2$ & $76 \pm 5$ & 112 & 100 & 109 \\
\hline CRM NIST $1643 \mathrm{e}^{\mathrm{c}}$ & - & - & - & - & $16.01 \pm 1.93$ & - & - & \\
\hline
\end{tabular}

${ }^{\mathrm{a}}$ Value \pm standard deviation, $\mathrm{n}=3$; ${ }^{\mathrm{b}} \mathrm{Cr}^{\mathrm{III}}$ concentration was evaluated from the difference between total $\mathrm{Cr}$ and $\mathrm{Cr}{ }^{\mathrm{VI}}$ concentration, (value \pm standard deviation, $\mathrm{n}=3$ ); ${ }^{\mathrm{c}}$ certified value $20.40 \pm 0.24 \mu \mathrm{g} \mathrm{L}-1 \mathrm{Cr}$; At 95\% confidence limit $(\mathrm{n}=3) \mathrm{t}_{\text {teorical }}=4.303$ and $\mathrm{t}_{\text {experimental }}=3.939$; LOQ: limit of quantification. 
Table 6. Comparison of the proposed method with other extraction methods for Cr determination

\begin{tabular}{|c|c|c|c|c|c|c|c|}
\hline $\begin{array}{l}\text { Sample treatment/ } \\
\text { spectrometric technique }\end{array}$ & $\begin{array}{c}\text { Chelating } \\
\text { reagent }\end{array}$ & $\begin{array}{c}\text { Extractant } \\
\text { solvent } / \mu \mathrm{L}\end{array}$ & $\begin{array}{l}\text { Disperser } \\
\text { solvent }\end{array}$ & $\begin{array}{c}\text { Sample } \\
\text { volume / } \mathrm{mL}\end{array}$ & \multicolumn{2}{|c|}{$\mathrm{LOD} /\left(\mu \mathrm{g} \mathrm{L}^{-1}\right)$} & Reference \\
\hline DLLME/FAAS & APDC & $\begin{array}{l}60 \text { carbon } \\
\text { tetrachloride }\end{array}$ & $2 \mathrm{~mL}$ ethanol & 25 & $0.07 \mathrm{Cr}^{\mathrm{VI}}$ & 0.08 total $\mathrm{Cr}$ & 26 \\
\hline DLLME/MIS-FAAS & APDC & $\begin{array}{l}100 \text { carbon } \\
\text { tetrachloride }\end{array}$ & $1 \mathrm{~mL}$ ethanol & 40 & $0.037 \mathrm{Cr}^{\mathrm{VI}}$ & - & 27 \\
\hline RTILs-DLLME/FAAS & DDTC & $40\left[\mathrm{C}_{8} \mathrm{MIM}\right]\left[\mathrm{PF}_{6}\right]$ & $1 \mathrm{~mL}$ methanol & 5 & $0.41 \mathrm{Cr}^{\mathrm{VI}}$ & $1.00 \mathrm{Cr}^{\mathrm{III}}$ & 44 \\
\hline M-IL-CIA-DLLME/FAAS & Schiff's base & $90 \mathrm{mg}[\mathrm{Hmim}]\left[\mathrm{PF}_{6}\right]$ & $500 \mu \mathrm{L}$ ethanol & 30 & - & 0.7 & 45 \\
\hline SALLME-IL/FAAS & DPC & $150\left[\mathrm{C}_{4} \mathrm{mim}\right]\left[\mathrm{BF}_{4}\right]$ & - & 10 & $1.25 \mathrm{Cr}^{\mathrm{VI}}$ & - & 46 \\
\hline DLLME/HR-CS FAAS & APDC & 50 1-undecanol & $\begin{array}{c}300 \mu \mathrm{L} \mathrm{Cr}{ }^{\mathrm{VI}} \\
275 \mu \mathrm{L} \text { total } \mathrm{Cr} \\
\text { ethanol }\end{array}$ & 9 & $0.35 \mathrm{Cr}^{\mathrm{VI}}$ & 6.7 total $\mathrm{Cr}$ & this work \\
\hline
\end{tabular}

LOD: limit of detection; DLLME: dispersive liquid-liquid microextraction; FAAS: flame atomic absorption spectrometry; MIS-FAAS: microsample injection system; RTILs: room temperature ionic liquids; APDC: ammonium pyrrolidine dithiocarbamate; DDTC: sodium diethyldithiocarbamate; $\left[\mathrm{C}_{8} \mathrm{MIM}\right]\left[\mathrm{PF}_{6}\right]$ : 1-octyl-3-methylimidazolium hexafluorophosophate; M-IL-CIA: modified ionic liquid cold-induced aggregation; Schiff's base: bis(2-methoxybenzaldehyde) ethylene diimine; $[\mathrm{Hmim}]\left[\mathrm{PF}_{6}\right]$ : 1-hexyl-3-methylimidazolium hexafluorophosphate; SALLME-IL: salt-assisted liquid-liquid microextraction with ionic liquid; DPC: 1,5-diphenylcarbazide; $\left[\mathrm{C}_{4} \mathrm{mim}\right]\left[\mathrm{BF}_{4}\right]$ : 1-butyl-3-methylimidazolium tetrafluoroborate.

elements has become of paramount importance, mainly when toxicological characteristics are dependent on the oxidation state, which can be seen for $\mathrm{Cr}^{\mathrm{III}}$ and $\mathrm{Cr}^{\mathrm{VI}}$. The DLLME procedure proposed in this paper made it possible to carry out the determination and speciation of chromium in different water samples by using reduced volumes of non-chloride solvents, 1-undecanol and ethanol, and a consequent reduction in residue produced. The combination of DLLME and HR-CS FAAS also made it possible to reach quantification limits, 1.1 and $22 \mu \mathrm{g} \mathrm{L} \mathrm{L}^{-1}$ for $\mathrm{Cr}^{\mathrm{VI}}$ and total $\mathrm{Cr}$, respectively, considerably below the acceptable levels of $\mathrm{Cr}$ established for drinking water.

\section{Supplementary Information}

Supplementary data (tables and figures) are available free of charge at http://jbcs.sbq.org.br as PDF file.

\section{Acknowledgments}

This research has been supported by National Council for Science and Technological Development (CNPq) and São Paulo Foundation Research (FAPESP Project No. 2011/19730-3). We thank Rodrigo Papai (PhD student) for assistance with GFAAS water sample analysis.

\section{References}

1. Scancar, J.; Milacic, R.; J. Anal. At. Spectrom. 2014, 29, 427.

2. Markiewicz, B.; Komorowicz, I.; Sajnóg, A.; Belter, M.; Baralkiewicz, D.; Talanta 2015, 132, 814.
3. Hsu, L. C.; Liu, Y. T.; Tzou, Y. M.; J. Hazard. Mater. 2015, 296, 230.

4. Matović, Z. D.; Jeremic, M. S.; Jelic, R. M.; Zlatar, M.; Jakovljević, I. Z.; Polyhedron 2013, 55, 131.

5. Templeton, D. M.; Ariese, F.; Cornelis, R.; Danielsson, L.; Muntau, H.; Leeuwen, H.; Lobinski, R.; Pure Appl. Chem. 2000, 72, 1453.

6. López-García, I.; Vicente-Martínez, Y.; Hernández-Córdoba, M.; Talanta 2015, 132, 23.

7. Galbeiro, R.; Garcia, S.; Gaubeur, I.; J. Trace Elem. Med. Biol. 2014, 28, 160.

8. Rezaee, M.; Assadi, Y.; Hosseimi, M. R. M.; Aghaee, E.; Ahmadi, F.; Berijani, S.; J. Chromatogr. A 2006, 1116, 1.

9. Gong, A.; Zhu, X.; Talanta 2015, 131, 603.

10. Leong, M. I.; Fuh, M. R.; Huang, S. D.; J. Chromatogr. A 2014, 1335, 2

11. Sereshti, H.; Khojeh, V.; Samadi, S.; Talanta 2011, 83, 885.

12. Pytlakowska, K.; Kozik, V.; Dabioch, M.; Talanta 2013, 110, 202.

13. Andruch, V.; Balogh, I. S.; Kocúrová, L.; Sandrejová, J.; J. Anal. At. Spectrom. 2013, 28, 19.

14. Gaubeur, I.; Aguirre, M. A.; Kovachev, N.; Hidalgo, M.; Canals, A.; Microchem. J. 2015, 121, 219.

15. Aguirre, M. A.; Legnaioli, S.; Almodóvar, F.; Hidalgo, M.; Palleschi, V.; Canals, A.; Spectrochim. Acta, Part B 2013, 79, 88.

16. de Jesus, A. M. D.; Aguirre, M. A.; Hidalgo, M.; Canals, A.; Pereira-Filho, E. R.; J. Anal. At. Spectrom. 2014, 29, 1813.

17. Aguirre, M. A.; Selva, E. J.; Hidalgo, M.; Canals, A.; Talanta 2015, 131, 348

18. Aguirre, M. A.; Nikolova, H.; Hidalgo, M.; Canals, A.; Anal. Methods 2015, 7, 877. 
19. Gaubeur, I.; Aguirre, M. A.; Kovachev, N.; Hidalgo, M.; Canals, A.; J. Anal. At. Spectrom. 2015, 30, 2541.

20. Vidal, L.; Silva, S. G.; Canals, A.; Nóbrega, J. A.; Talanta 2016, 148, 602.

21. Paz-Rodríguez, B.; Domínguez-González, M. R.; AboalSomoza, M.; Bermejo-Barrera, P.; Food Chem. 2015, 170, 492.

22. Oliveira, S. R.; Raposo Jr., J. L.; Neto, J. A. G.; Spectrochim. Acta, Part B 2009, 64, 593.

23. Oliveira, S. R.; Neto, J. A. G.; Nóbrega, J. A.; Jones, B. T.; Spectrochim. Acta, Part B 2010, 65, 316.

24. Welz, B.; Vale, M. G. R.; Pereira, E. R.; Castilho, I. N. B.; Dessuy, M. B.; J. Braz. Chem. Soc. 2014, 25, 799.

25. Welz, B.; Morés, S.; Carasek, E.; Vale, M. G. R.; Okruss, M.; Becker-Ross, H.; Appl. Spectrosc. Rev. 2010, 45, 327.

26. Hemmatkhah, P.; Bidari, A.; Jafarvand, S.; Hosseini, M. R. M.; Assadi, Y.; Microchim. Acta 2009, 166, 69.

27. Baig, J. A.; Hol, A.; Akdogan, A.; Kartal, A. A.; Divrikli, U.; Kazi, T. G.; Elci, L.; J. Anal. At. Spectrom. 2012, 27, 1509.

28. Oviedo, J. A.; de Jesus, A. M. D.; Fialho, L. L.; Pereira-Filho, E. R.; Quim. Nova 2014, 37, 249.

29. Welz, B.; Sperling, M.; Atomic Absorption Spectrometry, $3^{\text {rd }}$ ed.; Wiley-VCH: Weinheim, Germany, 1999.

30. Aggett, J.; O’Brien, G.; Analyst 1981, 106, 497.

31. Montgomery, D. C.; Design and Analysis of Experiments, $6^{\text {th }}$ ed.; Wiley: New York, USA, 2004.

32. Kotaś, J.; Stasicka, Z.; Environ. Pollut. 2000, 107, 263.

33. Paleologos, E. K.; Stalikas, C. D.; Tzouwara-Karayanni, S. M.; Pilidis, G. A.; Karayannis, M. I.; J. Anal. At. Spectrom. 2000, 15, 287.

34. Chen, H.; Du, P.; Chen, J.; Hu, S.; Li, S.; Liu, H.; Talanta 2010, $81,176$.

35. Paleologos, E. K.; Stalikas, C. D.; Karayannis, M. I.; Analyst 2001, 126, 389.
36. Tsogas, G. Z.; Giokas, D. L.; Vlessidis, A. G.; Evmiridis, N. P.; Spectrochim. Acta, Part B 2004, 59, 957.

37. Chwastowska, J.; Skwara, W.; Sterlinska, E.; Pszonicki, L.; Talanta 2005, 66, 1345.

38. World Health Organization (WHO), Guidelines for DrinkingWater Quality, http://www.who.int/water_sanitation_health/ dwq/fulltext.pdf., accessed in May 2016.

39. Ministério da Saúde, Portaria No. 2914, Dispõe sobre os Procedimentos de Controle e de Vigilância da Qualidade da Água para Consumo Humano e seu Padrão de Potabilidade, de 12 de Dezembro de 2011; http://bvsms.saude.gov.br/bvs/ saudelegis/gm/2011/prt2914_12_12_2011.html, accessed in May 2016.

40. European Commission (EC); Council Directive 98/83/EC; Quality of Water Intended for Human Consumption; Off. J. Eur. Communities L330 (05/12/1998) 0032-0054, http://ec.europa. eu/environment/water/water-drink/legislation_en.html, accessed in May 2016.

41. United States Environmental Protection Agency (US EPA); Chromium in Drinking Water; http://www.epa.gov/ dwstandardsregulations/chromium-drinking-water, accessed in May 2016.

42. Carletto, J. S.; Roux, K. C. D. P.; Maltez, H. F.; Martendal, E.; Carasek, E.; J. Hazard. Mater. 2008, 157, 88.

43. Callao, M. P.; TrAC, Trends Anal. Chem. 2014, 62, 86.

44. Wen, S.; Wu, J.; Zhu, X.; J. Mol. Liq. 2013, 180, 59.

45. Zeeb, M.; Ganjali, M. R.; Norouzi, P.; Food Anal. Methods 2013, 6, 1398.

46. Majidi, B.; Shemirani, F.; Microchim. Acta 2012, 176, 143.

Submitted: February 11, 2016

Published online: June 7, 2016

FAPESP has sponsored the publication of this article. 